\title{
Baș Makale: \\ Eğitsel Değerlendirme ve Bireyselleştirilmiş Eğitim Programı Hazırlama Süreci
}

\author{
Doç. Dr. Tevhide Kargın* \\ Ankara Üniversitesi
}

\begin{abstract}
Özet
Ĕ̆itsel değerlendirme süreci, engelli ya da risk durumunda olduğundan şüphe edilen çocukları ilk belirleme aşamasından başlayarak, gönderme öncesi süreç, gönderme, ayrıntılı değerlendirme, özel eğitim hizmetleri için uygunluğuna karar verme, yerleştirme, bireyselleştirilmiş eğitim programı hazırlama, uygulama ve değerlendirme-izleme aşamalarından oluşan bir süreci tanımlamak amacıyla kullanılan bir terimdir. Makalede bu aşamalar tanımlanmış ve her bir aşamada dikkat edilmesi gereken önemli noktalar vurgulanmaya çalışılmuştır.
\end{abstract}

Anahtar Sözcükler: Ĕ̌itsel Değerlendirme Süreci, Bireyselleştirilmiş Eğitim Programı

Abstract

Assessment procedures consist of screening, pre-referral, referral, evaluation, eligibility determination, placement, developing, implementation and monitoring of the individualized education programs (IEP), in this article all these steps were defined and the important issues in each step were emphasized.

Key Words: Assessment Procedures, Individualized Education Programs

Ülkemizde engelli öğrencilere sağlanan eğitim olanakları gün geçtikçe artmakta ve son on yılda daha fazla sayıda öğrenci bu olanaklardan yararlanmaktadır. Geçmişte engelli öğrencilerin eğitimleri söz konusu olduğunda bu eğitimin daha çok ayrı okullarda olması gerektiği düşünülür ve öğrenciler engel gruplarına yönelik açılan ayrı yatıl1/gündüzlü özel eğitim okullarına ya da özel eğitim sınıflarına yerleştirilirlerdi. Yetersizlikten etkilenme derecesi çok fazla olmayan öğrenciler ise hiçbir değerlendirme ve ardından da Bireyselleştirilmiş Eğitim Programı (BEP) hazırlama sürecine dahil edilmeden genel eğitim sınıflarında diğer öğrencilerle birlikte eğitim görürlerdi ve çoğu zaman da akademik ve uyum problemleriyle karşı karşıya kalırlardı. Ülkemizde engelli öğrencilere yönelik değerlendirme, yerleştirme ve BEP sürecine ilişkin yapılması

\footnotetext{
*Ankara Üniversitesi Eğitim Bilimleri Fakültesi. tkargin@hotmail.com
} 
gereken düzenlemeler 1997 yılında yasal olarak ele alınmıştır.

1997 y1lında kabul edilen 573 Say1lı Kanun Hükmünde Kararname ve ardından 2000 yılında yürürlüğe giren Özel Eğitim Hizmetleri Yönetmeliği ile engelli bireylerin eğitsel değerlendirmelerinin nasıl olması gerektiği, uygun eğitim ortamları, yerleştirme ve BEP hazırlama sürecinin nasıl oluşturulması gerektiği ilk kez ayrıntılarıyla tanımlanmıştır. İlgili yönetmeliğin ikinci kısım ikinci bölümünde Madde 11'de eğitsel tanılama süreci "eğitsel amaçla bireyin tüm gelişim ve disiplin alanlarındaki özelliklerinin belirlenerek değerlendirilmesi” olarak tanımlanmıştır. Aynı madde "Bireyin eğitsel tanılaması rehberlik ve araştırma merkezinde oluşturulan eğitsel tanılama, izleme ve değerlendirme ekibi tarafından yapılır" ifadesi ile devam etmektedir. Yine aynı yönetmeliğin ikinci kısım dördüncü bölümünde yerleştirme, altıncı kısım birinci bölümde Bireyselleştirilmiş Eğitim Programı (BEP) hazırlama süreci tanımlanmış bulunmaktadır. Buna göre Madde 62'de BEP “özel eğitim gerektiren birey için geliştirilen ve ailesi tarafından onaylanan bireyselleştirilmiş eğitim programı, bireyin, ailenin, öğretmenin gereksinimleri doğrultusunda hazırlanan ve hedeflenen amaçlarda verilecek destek eğitim hizmetlerini içeren özel eğitim programı" olarak tanımlanmaktadır (MEB, 2000). 1997 yılında kabul edilen 573 sayılı Kanun Hükmünde Kararname'den sonra 2005 yılında yürürlüğe giren 5378 sayılı kanun ve ardından da 2006 yılında çıkartılan Özel Eğitim Hizmetleri Yönetmeliğinde eğitsel değerlendirme ve BEP süreci tanımlanmıştır. 2006 yılında yürürlüğe giren yönetmeliğin ikinci kısım birinci bölümünde Madde 7'de eğitsel değerlendirme süreci sonunda engelli bireyin yerleştirilmesi sürecinin nasıl olması gerektiği şu şekilde ifade edilmiştir (http://rega.basbakanlik.gov.tr/): "Eğitsel değerlendirme ve tanılama sürecinde, eğitsel amaçla bireyin tüm gelişim alanındaki özellikleri ve akademik disiplin alanlarındaki yeterlilikleri ile eğitim ihtiyaçları belirlenerek en az sınırlandırılmış eğitim ortamına ve özel eğitim hizmetine karar verilir."
Görüldüğü gibi 2006 yılında yürürlüğe giren Özel Eğitim Hizmetleri Yönetmeliğinde daha önceki yönetmelikten farklı olarak eğitsel değerlendirme sürecinde en az sınırlandırıcı ortam kavramı kullanmıştır. Bilindiği gibi en az kısıtlayıcı ya da sinırlandırıcı ortam, engelli bireyin en üst düzeyde performansını sergileyeceği ortamdır ve bu ortam belirlenirken öncelikle normal gelişim özelliği gösteren akranlarıyla bir arada bulunmasına özen gösterilir. Bu bakımdan 2006 yönetmeliğinin en az sınırlandırıcı ortam seçimini eğitsel değerlendirme süreci sonunda verilecek bir karar olarak görmesi sevindiricidir. 2006 y1lında yürürlüğe giren Özel Eğitim Hizmetleri Yönetmeliğinde, 2000 yönetmeliğinden farklı olarak Özel Eğitim Değerlendirme Kurulu tarafından özel eğitime ihtiyacı olan her birey için "Eğitim Planı" hazırlanacağı belirtilmiştir. Bu durum "Eğitim planında, bireyin tüm gelişim ve akademik disiplin alanlarındaki performansı ile öncelikli eğitim ihtiyaçlarına göre belirlenen yıllık amaçlar yer alır" şeklinde ifade edilmiştir (http://rega.basbakanlik.gov.tr/). Böylelikle engelli birey için bir yıllık hedeflerin neler olacağ değerlendirme ekibi tarafından RAM'larda belirlenirken, bireyin BEP'nın eğitim aldığı okulda ya da kurumda oluşturulan BEP ekibi tarafından hazırlanması gerektiği de ilgili yönetmelikte açıkça ifade edilmektedir.

Eğitsel değerlendirme, yerleştirme ve BEP hazırlama süreçlerinin hem 2000 yılında yürürlüğe giren yönetmelikte; hem de 2006 yılındaki yönetmelikte yasal olarak tanımlanmış olması, özel eğitim hizmetlerinin ülke genelinde bir bütünlük içinde yürütülmesini sağlamak açısından önemli görülmektedir. Eğitsel değerlendirme süreci yasal olarak tanımlanmış olmakla birlikte, bu süreçte izlenmesi gereken adımların nasıl olması gerektiği belirlenmesine gereksinim vardır.

$\mathrm{Bu}$ gereksinimle izleyen bölümde eğitsel değerlendirme süreci açıklanmış, Şekil 1'de ilk belirleme aşamasından başlayarak ayrıntılı değerlendirme sürecine kadar izlenen basamaklar, şekil 2'de ise tüm değerlendirme ve BEP hazırlama süreci tanımlanmıştır. 


\section{Eğitsel değerlendirme süreci}

Değerlendirme kabaca, bir birey hakkında karar vermek için yapılan bilgi toplama sürecidir ve bu süreç farklı amaçlar için gerçekleştirilir. Bu amaçlar, engelli ya da risk durumunda olduğu düşünülen öğrencileri belirleme, sınıflama ve programa yerleştirme, bireyselleştirilmiş eğitim programı hazırlama, uygun hedef ve amaçları seçme, öğrenme stratejilerini belirleme ve uygulanan program sonucunda gelişmenin değerlendirilmesi olarak siralanabilir (Taylor, 1997).

Değerlendirmede kullanılacak araçlar, yöntemler ile değerlendirmenin nerede ve kimler tarafından yapılacağı, değerlendirmenin yukarıda sıralan amaçlarına göre farklılık göstermektedir. Şekil 1'de de görüldüğü gibi ilk belirleme aşamasında yapılan değerlendirme daha çok tarama amacıyla yapılan değerlendirmedir ve genel eğitim okullarında/sınıflarında öğrenim gören engelli ya da risk durumunda olduğundan şüphe edilen öğrencileri belirlemek için yapılır (Spinelli, 2002; Wood, 1998). İlk belirleme aşaması informal bir süreçtir ve gözlem, görüşme, kontrol listesi, ölçüt bağımlı ölçü aracı gibi informal değerlendirme araçları kullanılarak gerçekleştirilir.

\section{Şekil 1}

Gönderme Öncesi Süreç ve Ayrıntılı Değerlendirme Süreci (Turnbull, A.; Turnbull, R. \& Wehmeyer, M.L., 2007)

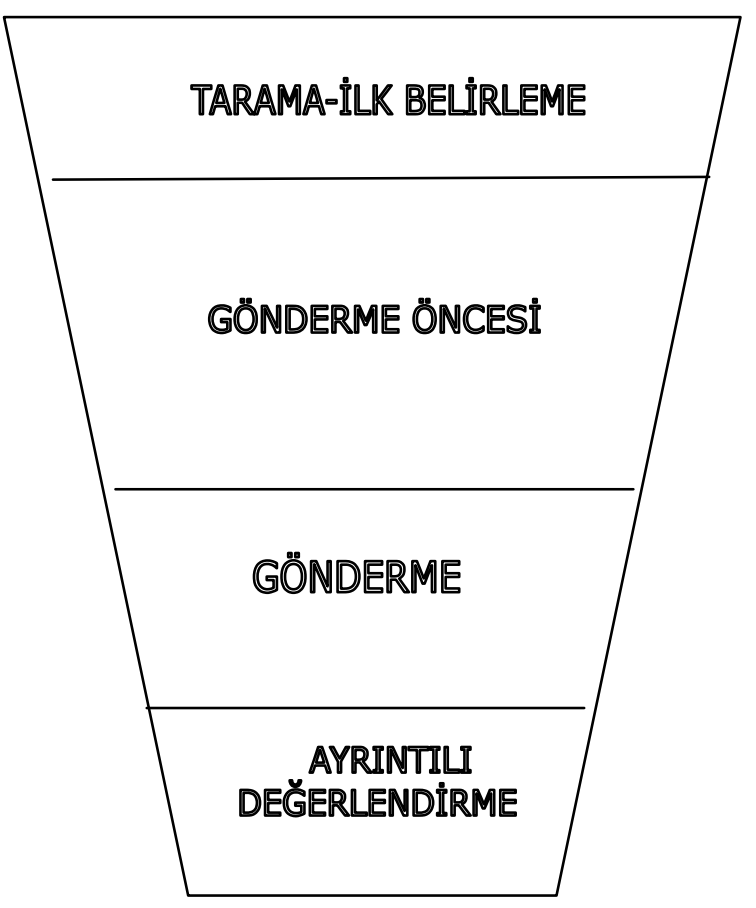

Ilk belirleme basamağının temel amacı okulun/ sinıfın temel gereklerini yerine getirmede güçlük yaşayan, öğrenme özellikleri nedeniyle derslerde akranlarından geri kalan ve desteğe gereksinim duyan ögrencileri belirlemektir 
(Spinelli, 2002). İlk belirleme, sınıf öğretmeleri ile okul rehberlik servislerinin birlikte çalışmasını gerektirir. Genel eğitim sınıflarında engelli ya da risk durumunda olduğundan şüphe edilen öğrencileri belirlemek, bu öğrencilere sınıf içinde eğitsel destek sağlamak için ön koşuldur ve oldukça önemlidir. $\mathrm{Bu}$ nedenle öğrencilerin daha sonra kendilerine sağlanacak eğitsel destekten yararlanabilmeleri için ilk belirleme sürecinin olabildiğince çabuk gerçekleştirilmesi gerekmektedir. Yine Şekil 1'de görüldügü gibi belirleme amaciyla yapilan tarama sürecine okulda bulunan tüm öğrenciler dahil edilirken ilerleyen basamaklara daha az sayıda öğrenci dahil edilmektedir (Turnbull \& ark. 2007).

Engelli ya da risk durumunda olduğu düşünülen öğrencilerin belirlenmesinin ardından, bu öğrencileri genel eğitim sınıfıyla bütünleştirmek için çeşitli önlemlerin alındığı, eğitimsel müdahalelerin yapıldığı gönderme öncesi süreç başlatılır (Mastropieri \& Scruggs, 2000; Turnbull \& ark. 2007; Wood, 1998). Gönderme öncesi süreç, öğrenciyi ayrıntılı değerlendirme için Rehberlik Araştırma Merkezlerine göndermeden önce daha çok sınıf öğretmeninin eğitim yöntemlerinde, materyallerinde, sınıfın fiziksel çevresinin düzenlenmesinde, amaçlarda ve gerektiğinde ev ödevlerinde uyarlamalar yapması ve öğrencinin genel eğitim sınıfında eğitim görmesi/kalması için yapılan çabalardır. $\mathrm{Bu}$ sürecin temel amacı, daha yoğun bir eğitime gereksinimi olmayan bir öğrencinin gereksiz yere değerlendirmeye alınmasını önlemek ve böylece öğrenciyi ayrıntılı değerlendirme süreci sonunda ortaya çıkabilecek etiketlemeden kurtarmaktır (Kirk, Gallagher, Anastasiow \& Coleman, 2006). Şekil 1'de de bu sürecin daha az öğrenci için uygulandığ 1 görülmektedir. Gönderme öncesi süreç sistematik ve planlı bir biçimde uygulanmalıdır. Bu süreç öğretmenin sorumluluğunda görülmekle birlikte, okul içinde özel gereksinimli öğrencilerin sınıfa katılımını sağlamada rehber öğretmenler ve okulda bulunan diğer öğretmenler, sınıf öğretmenini ve öğrenciyi desteklemelidirler (Heward, 2006; Mastropieri \& Scruggs, 2000). Gönderme öncesi süreç ilk belirleme aşamasında olduğu gibi informal bir süreçtir ve informal değerlendirme araçları kullanılır. Bu süreçte eğitimsel planlama ile birlikte, değerlendirme için ayrılan zaman da önemlidir. Gönderme öncesi sürecin planlanması için ayrılan zaman gereğinden kısa ya da gereğinden uzun olmamalıdır. Ayrilan zamanın kisa olması, öğrencideki ilerlemeyi görmeye engel oluşturabilecekken, zamanın uzun olması öğrencinin ayrıntılı değerlendirme sonucunda yararlanacağı yasal haklara ve eğitsel düzenlemelere kavuşmasına engel oluşturabilir. Alanda yapılan çalışmalar, sistematik ve planlı bir biçimde uygulanan gönderme öncesi sürecin pek çok özel gereksinimli öğrencinin ayrıntılı değerlendirilmesine gerek kalmadan genel eğitim sınıfında eğitimlerini sürdürmelerinde etkili olduğunu göstermektedir (Kirk \& ark., 2006; Strickland \& Turnbull, 1990; Turnbull \& ark., 2007).

Gönderme öncesi süreçte öğrencinin genel eğitim sınıfına akademik ve sosyal yönden katılımı beklenenin altında ise başka bir deyişle öğrenci gönderme öncesi süreçte planlanan hedefler doğrultusunda gelişme gösteremiyorsa ayrıntılı değerlendirme için gönderme süreci başlatılır (Kirk \& ark., 2006). Gönderme sürecinde öğrenci için alınan tüm önlemler, yapılan tüm uyarlamalar, uyarlama sonuçları ve öğrenci hakkında toplanan tüm bilgiler rapor haline getirilir. Böylece ayrıntılı değerlendirme sürecine öğrenci daha fazla bilgi ile gönderilmiş olur. Öğrencinin ayrıntılı değerlendirmeye gönderilmesi kararı, sınıf ögrretmeni ile birlikte okul rehberlik servisi ve öğrencinin ailesinin birlikte vermesi gereken bir karardır.

Ayrıntılı değerlendirme süreci formal bir süreçtir ve bu süreçte formal değerlendirme araçları olan standart testler kullanılır. Ülkemizde en yaygın kullanılan standart değerlendirme araçları zeka testleridir. Formal değerlendirme sürecinde öğrencinin özel eğitim hizmetlerine uygun olup olmadığına yani özel eğitim kapsamı içinde düşünülüp düşünülmeyeceğine karar verilir. Ayrıntılı değerlendirme sürecinde formal yolla elde edilen bilginin informal değerlendirme araçlarıyla desteklenmesi birey hakkında daha doğru kararlar verilmesine yardım eder. Rehberlik araştırma merkezlerinde "Eğitsel Değerlendirme ve İzleme Ekibi" tarafından yapılan ayrıntılı değerlendirme ile öğrencinin özel eğitim hizmetlerinden 
yararlanmayı gerektirecek bir engele sahip olup olmadığı belirlenmeye çalışılır. Öğrencinin tanılanmış bir engelinin olması bu öğrencinin engelli çocuklara sağlanacak eğitim hizmetlerinden yararlanacağı bir ortama yerleştirilmesi (özel eğitim okuluna/sınıfına ya da kaynaştırmaya yerleştirilmesi gibi) bakımından yeterli görülmemektedir. Öğrencinin özel eğitim hizmetlerine uygun olup olmadı̆̆ına karar vermek için tanılanmış bir engeli ile birlikte, almış olduğu tanının eğitsel performansı üzerinde olumsuz etkiye yol açması ve bu olumsuz etkinin ortadan kaldırılabilmesi için özel olarak hazırlanmış programlara, araç gereçlere ve personele gereksinim duyulması gerekmektedir (Strickland \& Turnbull, 1990) .

Özel eğitim hizmetleri için uygunluğuna karar vermede gerekli olan bu ölçütler Amerika Birleşik Devletleri'nde 1975 yilında kabul edilen PL. 94142 nolu yasada ifade edilmiştir. Buna göre bir öğrencinin özel eğitim ya da genel eğitim okuluna yerleştirilmesine karar verilebilmesi ve bireyselleştirilmiş eğitim programı hazırlanabilmesi için öğrencinin yalnızca tanılanmış bir engelinin olması yeterli değildir. İki durumun daha bulunması gerekmektedir. Örneğin bir öğrencinin özel eğitim hizmetlerinden yararlanması için o öğrencinin işitme engelinin olmasının yanı sıra, söz konusu işitme engelinin öğrencinin eğitsel performansını olumsuz etkilemesi ve bu olumsuz etkinin işitme cihazı edindirme ve ön sirada oturtma gibi basit birkaç uyarlama ile ortadan kaldırılabilecek nitelikte olmaması gerekmektedir. Ayrıntılı değerlendirme sonucunda verilecek uygunluk kararı, değerlendirme ekibinin birlikte, objektif olarak ve informal değerlendirme araçlarından elde edilen sonuçları da içerecek şekilde verilmesi gereken bir karardır. Aile bu uygunluk kararı için yapılan toplantıların aktif bir üyesi olmalıdır (Overton, 2006).

Ülkemizde rehberlik araştırma merkezleri aracılığı ile gerçekleştirilen ayrıntılı değerlendirme süreci sınıflama ve yerleştirme ile sonuçlanan bir süreçtir ve öğrencinin eğitimsel geleceği hakkında son derece önemli kararlar alınır. Bu nedenle bu sürecin eğitsel değerlendirmenin temel ilkelerini dikkate alarak gerçekleştirilmesinde fayda vardır.
Değerlendirmenin temel ilkelerini şu şekilde sıralamak mümkündür:

Değerlendirme sürecinin en önemli ilkelerinden birisi değerlendirmede farklılık ilkesidir. Bu ilkeye göre değerlendirme, farklı zamanlarda, farklı kişiler tarafindan, farklı ortamlarda, farklı değerlendirme yöntemleri ve araçlarıyla gerçekleştirilmelidir (Heward, 2006). Buna göre tek bir ortamda, tek bir değerlendirme aracı ve yöntemiyle ve tek bir kişi tarafından yapılan değerlendirme yeterince güvenilir değildir. Ayrıntılı değerlendirme süreci daha çok formal değerlendirme süreci olmakla birlikte; bu süreçte formal değerlendirme araçlarıyla yapılan değerlendirme, informal değerlendirme araçlarından elde edilen bilgiyle desteklenmelidir. Ayrıca değerlendirme tek bir kişi tarafindan değil, özel eğitim öğretmeni, sınıf öğretmeni, okul psikoloğu gibi öğrencinin eğitim programına katılan diğer uzmanları içeren bir ekip tarafından yapılmalıdır.

Değerlendirme sürecine ilişkin bir diğer ilke, bu sürecin belirli bir amaç için aktif, devam eden bir süreç olmasıdır. Değerlendirmenin bu özelliği onun bir kez başlayıp biten bir süreç olmasını engellemekte ve böylece değerlendirme sonucunda yanlış kararlar alınmasının önüne geçilmeye çalışılmaktadır (Taylor, 1997). Değerlendirmeyi tek bir oturumda başlayan ve biten bir süreç olarak görmek, hem tek bir değerlendirme ile birey hakkında doğru karar alınabileceği, hem de bireyin performansının her durumda aynı olacağ sayıltısıyla hareket edildiğini ifade eder ki bu iki sayıltı da çürütülmeye mahkûmdur. $\mathrm{Bu}$ nedenle değerlendirmenin devam eden bir süreç olarak görülmesi gerekmektedir.

Değerlendirme sürecinin üçüncü ilkesi ise bu sürecin bireyselleştirilmiş bir süreç olması ve değerlendirme stratejileri olabildiğince bireyselleştirilmesidir (Turnbull \& ark. 2007). Örneğin aynı testin tüm engelli öğrencilere kullanılması yalnızca uygunsuz değil, aynı zamanda pratik olarak da imkansızdır. Çünkü bu bireyler bireyselleştirilmiş bir yaklaşımı gerektirecek bireysel özelliklere sahiptirler. Öğrencilerin bireysel özellikleri, engel durumları ve engelden etkilenme dereceleri göz önünde bulundurularak 
uygun değerlendirme araçları seçilmelidir. Örneğin işitme kayıplı bir çocuk için dile dayalı bir aracın seçimi ya da serebral paralizi olan bir çocuk için performans testlerinin kullanımı uygun olmayabilir.

Değerlendirme özellikle psikolojik ve eğitsel değerlendirme, testlerle aynı anlamda düşünülse de, değerlendirme sürecinin test uygulamaktan, sonuçları puanlamak ve kayıt etmekten daha fazlasını içeren bir süreç olması gerektiği değerlendirmenin bir diğer ilkesidir. $\mathrm{Bu}$ süreç testleri de içine alan farklı araçlar ve teknikler tarafindan sağlanan bilginin dikkatlice analizini içermektedir ve bu analiz sonucunda elde edilen sonuçlar işlevsel ve uygun kararları içermelidir. Hangi aracın ve tekniğin uygun olduğuna karar vermek değerlendirmenin amacına bağlı olarak değişiklik gösterecektir (Salvia \& Ysseldyke, 2001; Turnbull \& ark. 2007). Eğitsel değerlendirme test verme sürecini de içeren kapsamlı bir süreçtir. Test verme, yapılandırılmış ortamda öğrencinin sorulara tepkilerini içerir. Testin ne kadar yapılandırılmış olduğuna bağlı olarak test sonuçları da çeşitli puanlar, edinilmiş becerilerin bir listesi, ortalama puanlar ve yüzdelikler şeklinde ifade edilebilir.

Testler engelli çocuk hakkında bilgi toplamak için kullanılan eğitsel değerlendirmedeki birçok stratejiden yalnızca birisidir. Önceleri testler değerlendirmenin tek aracı gibi görülür ve daha çok da tanı ve teşhis kavramları ile birlikte kullanılırdı. Teşhis, tıp alanından alınan bir terimdir ve bu kapsam içinde kullanılır. Hastalığın nedenleri ile tedavisine ilişkin sorulara yanıt bulmaya çalışan tıbbi tanılama genellikle bir etiketleme ile son bulur ve bu etiketleme tedaviye işaret eder. $\mathrm{Bu}$ görüşün aksine, eğitimde engelli öğrencinin değerlendirilmesi sonucu oluşan böyle bir etiketleme ve bu etikete dayalı olarak oluşacak bir tedavi belirlemek her zaman istendik sonuçlar elde etmemize olanak vermez. Eğer öğrenci engelli olarak etiketlendiyse, etiket yalnızca öğrencinin özel eğitim hizmetleri için uygunluğunu belirlemede önemlidir ve öğrenme probleminin kesin bir nedenine işaret etmez. Eğitsel değerlendirme bireyin özel eğitime gereksinimi olup olmadı̆̆ını belirlemenin yanında, bireyin performansı ile güçlü ve zayıf yönleri hakkında bilgi vererek birey için oluşturulacak programın hedeflerini belirlemeye de olanak verir (Taylor, 1997; Tindal \& Marston, 1990).

Değerlendirmede kullanılacak formal değerlendirme araçlarının öğrencinin içinde yaşadığı sosyal ve kültürel çevreye uygun araçlar olması gerektiği bir diğer ilkedir. Eğer kullanılan araçlar-ki genellikle bunlar formal değerlendirme araçları olan testler ve çoğunlukla da zeka testleridir. $\mathrm{Bu}$ testlerin öğrencinin içinde yaşadığı kültüre, kullandığı dile göre geliştirilmiş normları olmalı ve birey içinde yaşadığ 1 kültürün özelliğinden dolayı bu testlerde başarısız olmamalıdır. Değerlendirmenin bu ilkesi ayrımcılığa yol açmayan değerlendirme olarak da adlandırılmaktadır. Ayrıca değerlendirmede kullanılan formal değerlendirme araçlarının geçerlik ve güvenilirliğinin yüksek olması yani psikometrik özelliklerinin değerlendirmenin amacına uygun/ yeterli olması, bu araçların uygulanması ve puanlanması konusunda eğitim almış bireyler tarafindan uygulanması değerlendirmede dikkat edilmesi gereken bir diğer ilkedir (Turnbull \& ark., 2007).

Engelli çocukların eğitsel değerlendirilmesi, çocuk için özel hizmetler hakkında eğitimsel ve yasal kararlar vermek amaciyla çeşitli bilgilerin toplanmasıdır. Özel eğitimci sınıftaki davranışlarla ilgili bilgileri toplar. Bununla birlikte eğitsel değerlendirme aynı zamanda engelli öğrencinin öğrenme problemini anlamak için yapılan disiplinlerarası değerlendirmenin yalnızca bir parçasıdır. Sınıf öğretmeni, rehber öğretmen ile birlikte özel eğitim hizmetleri dışındaki ilgili hizmetleri sunan fizyoterapist, doktor ve konuşma dil uzmanı gibi diğer uzmanlar da değerlendirme ekibinin diğer bileşenleridir. $\mathrm{Bu}$ nedenle değerlendirmenin ilgili hizmetleri sunan uzmanları da içermesi değerlendirmenin diğer bir ilkesini oluşturmaktadır.

Eğitsel değerlendirmede önemli bir ilke de bireyin akademik özellikleri kadar, okul başarısını etkileyebilecek dil ve sosyal beceriler gibi diğer faktörlerin de değerlendirilmesidir. Buna göre bireyin performansı, çevresel faktörleri de (içinde yaşadığı çevrenin ve ailenin özellikleri) göz önünde bulunduracak şekilde akademik, dil ve sosyal beceriler gibi bütün alanlarda ve okul, ev gibi 
bütün ortamlarda değerlendirilerek belirlenmelidir (Tindal \& Marston, 1990).

Eğitsel değerlendirmenin sonuncu ilkesi ise her yaşta ve dönemde değerlendirmenin mümkün olduğudur. Eğitsel değerlendirme erken çocukluktan başlayarak yetişkinliğe kadar geçen süreler içinde yapılır. Bebeklerin ve küçük çocukların dildeki, motor alanlardaki, bilişsel becerilerdeki, sosyal ve duygusal alanlardaki davranışları ile diğer becerileri ayrı ayrı ve birinin diğeri üzerindeki ortak etkileri ile birlikte incelenir. Yetişkinliğe geçişte, okul dünyasından iş dünyasına geçişte meslekler, yüksek öğrenim ve diğer yetişkin konuları da eğitsel değerlendirme süreci içinde dikkatlice incelenir.

Görüldüğü gibi bireyin özel eğitim ve ilgili hizmetlere gereksinimi olup olmadığını belirlemek amacıyla gerçekleştirilen ayrıntılı değerlendirme süreci çok yönlü ve sistematik bir çabayı gerektiren bir süreçtir. Şekil 2'de de görüldüğü gibi ayrıntılı değerlendirme sonucunda eğer bireyin özel eğitim hizmetlerinden yararlanmasının uygun olduğu düşünülürse, hazırlanacak programın temel hedeflerinin neler olması gerektiği de belirlenerek yerleştirme kararı verilir (Heward, 2006). Yerleştirme kararı ayrı yatılı/gündüzlü özel eğitim okulu, genel eğitim okulları bünyesindeki özel eğitim sınıfları ya da kaynaştırma ortamı olabilir. Kaynaştırma ortamına yerleştirme kararı verilirken öğrencinin kaynaştırmada ne kadar özel eğitim desteği alacağına da karar verilir. Kaynaştırmada alınabilecek özel eğitim desteği, alan yazında kaynak oda, danışman yardımlı genel eğitim sınıfı, özel eğitim öğretmeni yardımlı genel eğitim sınıfı ve gezici öğretmenlik olarak siralanmakla birlikte, ülkemizde kaynaştırma destek eğitim hizmetleri oldukça sinırlı olup sistematik olarak da yürütülmemektedir (Sucuoğlu \& Kargın, 2006).

Ayrıntılı değerlendirme süreci sonunda özel eğitim hizmetlerine uygunluğuna karar verilen öğrenci için yerleştirme kararı ve ardından da BEP hazırlama kararı verilir. $\mathrm{Bu}$ aşamada eğitsel değerlendirme sürecini gerçekleştiren rehberlik araştırma merkezlerinin, öğrencinin BEP'ında hangi alanlarda destekleneceğini belirlemesi beklenir. Yerleştirme ile birlikte BEP hazırlama süreci başlar.

\section{Bireyselleştirilmiş Eğitim Programı Hazırlama Süreci}

Bireyselleştirilmiş eğitim programı, özel eğitim hizmetlerine uygunluğuna karar verilen bireyler için sağlanacak özel eğitim hizmetlerinin nerede, ne zaman, ne kadar süreyle, kimler tarafından ve hangi amaçları gerçekleştirmek üzere uygulanacağını gösteren bir plandır. Bu tanımda özellikle üzerinde durulması gereken bir konu vardır ki o da bireyselleştirilmiş eğitim programının özel eğitim hizmetlerine uygunluğuna karar verilen ve yerleştirilmesine karar verilen bireyler için hazırlanacak olmasıdır. Gönderme öncesi süreçte gönderme öncesi müdahale programı hazırlanırken, ayrıntılı değerlendirme süreci sonunda BEP hazırlanir.

BEP aynı zamanda hizmet alanlarla hizmet verenlerin üzerinde anlaşmaya varmış oldukları bir sözleşmedir. Hizmet verenler, engelli bireyin eğitiminden sorumlu tüm bireyler (özel eğitim öğretmeni, genel eğitim/ sınıf öğretmeni, rehber öğretmen, psikolog gibi), hizmet alanlar ise engelli bireyin ailesi ve bazı durumlarda da bireyin kendisidir. Buna göre BEP, tek bir kişi tarafından hazırlanan bir program olmaktan daha çok, engelli bireyin eğitiminden sorumlu tüm bireylerin bu programın hazırlanmasına aktif bir biçimde katılımlarını ve belirlenen hedefleri tüm katılanların benimsemesini gerektiren bir programdir.

Tüm bunlarla birlikte BEP, yasal bir zorunluluktur. Ülkemizde 2000 yılında kabul edilen Özel Eğitim Hizmetleri Yönetmeliği ile özel gereksinimli olarak belirlenen her çocuk için BEP hazırlanması yasal bir zorunluluk olarak kabul edilmiş ve ilgili yönetmeliğin 62 . ve 63 maddelerinde ifade edilmiştir. 62. maddede bireyselleştirilmiş eğitim programı “özel eğitim gerektiren birey için hazırlanan ve ailesi tarafından onaylanan bireyselleştirilmiş eğitim programı; bireyin, ailenin, öğretmenin gereksinimleri doğrultusunda hazırlanan ve hedeflenen amaçlarda verilecek destek eğitim hizmetlerini de içeren özel eğitim programıdır" şeklinde tanımlanmıştır. 63. maddede ise özel eğitim ve kaynaştırma uygulamaları yapılan okul ve kurumlarda BEP'nı geliştirmek, izlemek ve değerlendirmek amacıyla "Bireyselleştirilmiş 
Eğitim Programı Geliştirme Birimi” kurulması ifade edilmiştir. 64. maddede de bu birimde yer alan üyelerin görevleri tanımlanmıştır. 2006 yılında yürürlüğe giren Özel Eğitim Hizmetleri Yönetmeliğinin Sekizinci Kısmında Madde 69 'da ise $\mathrm{BEP}$, “Özel eğitime ihtiyacı olan bireylerin gelişim özellikleri, eğitim performansları ve ihtiyaçları doğrultusunda hedeflenen amaçlara yönelik hazırlanan ve bu bireylere verilecek destek eğitim hizmetlerini de içeren özel eğitim programı" şeklinde tanımlanmıştır. Madde 74'te BEP Geliştirme Birimi Üyeleri, sınıf, alan, gezerek özel eğitim görevi yapan öğretmen, eğitim programlarını hazırlamakla görevlendirilen öğretmen ile rehber öğretmen, özel eğitim değerlendirme kurulu üyesi, öğrenci velisi ve öğrencinin kendisi olarak belirlenmiştir ( http://rega.basbakanlik.gov.tr/ ).

Buna göre ülkemizde yasal olarak da tanımlanmış bulunan BEP, temelde öğrencinin nereye ve nasıl ulaşılacağını belirten bir yol haritasıdır ve özel gereksinimli öğrenciye verilecek hizmetlerin yazılı bir kaydıdır (Olson \& Platt, 2004). BEP, aşağıdaki elemanlardan oluşur (Strickland \& Turnbull, 1990).

a. Öğrencinin şimdiki/varolan eğitsel performans düzeyinin ifadesi.

b. Öğrenciye bir akademik yıl sonunda kazandırılması planlanan uzun dönemli hedefler (yıllık hedefler).

c. Uzun dönemli hedeflere ulaşmak için gerekli olan kısa dönemli hedefler.

d. Belirlenen hedeflere ulaşmada kullanılacak olan öğretim yöntemleri ve materyaller.

e. Kısa dönemli hedeflere ulaşmak için gerekli olan zamanın başlama ve bitiş tarihleri.

f. Belirlenen hedeflere ulaşılıp ulaşılmadığını belirlemek için kullanılacak izleme ve değerlendirme.

g. Öğrenciye sağlanacak ek özel eğitim hizmetlerinin nerede, ne zaman, kimler tarafindan ve ne kadar süreyle verileceğinin belirlenmesi.

Görüldüğü gibi, bireyselleştirilmiş eğitim programı özel gereksinimli öğrenciye kazandırılacak davranışların neler olduğunu, bunların nasıl, nerede, ne kadar süreyle ve ne zaman kazandırılacağını planlayan bir dokümandır. Hedeflere ulaşma derecesini belirlemek üzere, değerlendirme yöntemi ile ölçütleri de bu dokümanda yer alır.

Öğrencinin varolan performans düzeyi, BEP'te yer alması gereken elemanlardan birisidir ve öğrencinin neleri yapıp yapamadığının yazılı kaydıdır. Performans düzeyi belirleme, öğrenci için oluşturulacak uzun ve kısa dönemli amaçlara temel oluşturacağ 1 için son derece önemlidir. Performans düzeyinin ayrıntılı ve çocuğu tüm yönleriyle tanımlayacak biçimde gerçekçi belirlenmesi amaçların da gerçekçi olmasını diğer bir deyişle ulaşılabilir ve kapsamlı olmasını sağlayacaktır.

Performans düzeyi belirleme eğitsel değerlendirme süreci sonucunda gerçekleştirilir. Öğrencinin farklı alanlarda akademik, motor, duygusal ve sosyal becerilerdeki yapabildikleri ve yapamadıkları çoğunlukla informal değerlendirme araçları ile belirlenmeye çalışılır. Daha çok öğretmen yapımı olarak bilinen informal değerlendirme araçlarını uygulamak için, formal değerlendirme araçlarında (standart testler) olduğu gibi uzmanlık gerekmeyebilir. Gözlem, görüşme, yazılı sınavlar, hata analizi, çalışma örneği analizi, ev ödevleri, çalışma kağıtları, ölçüt bağımlı araçlar gibi informal değerlendirme araçları öğrencinin bir becerideki ustalık derecesini belirlemeyi amaçlar. Varolan performans düzeyinin belirlenmesinde kullanılan bu araçlar daha çok ayrı okullarda ya da kaynaştırılan öğrencinin bulunduğu sınıftaki ögrretmenler tarafindan uygulanmakla birlikte, doğru ve kapsamlı bir değerlendirme için sınıftan sorumlu olan öğretmenin yanı sıra, rehber öğretmen ile okuldaki diğer öğretmenler de bu süreçte aktif görev almalıdır.

Performans düzeyi ifadeleri ölçülebilir ve gözlenebilir bir biçimde ifade edilmelidir. Ölçülemeyen ve gözlenemeyen ifadelerden hedefler oluşturmak mümkün değildir. $\mathrm{Bu}$ nedenle performans düzeyi ifadelerinin uzun ve kısa dönemli amaç oluşturmaya uygun olması gerekmektedir. Örneğin "Ali matematikte zorlanır." gibi bir performans düzeyi ifadesinde öğrencinin yaşadığı güçlük tanımlanmış değildir. Her birey 
matematikte zorlanabilir. Bu zorluğun ne olduğu ayrıntılı bir biçimde tanımlanmalıdır. Onun yerine "Ali, toplama işleminde iki basamaklı bir sayıyla iki basamaklı bir sayıyı toplamları eldeli olacak şekilde toplarken 4 denemenin dördünde elde olan sayıyı onlar basamağına eklemeden yazar." şeklinde bir ifade öğrencinin yaşadığ 1 güçlüğü tanımlamada daha yeterlidir.

\section{Performans düzeyi ifadelerinde} performansın ölçütü belirlenmelidir (Gibb \& Dyches, 2000). Buna göre öğrencinin bir davranış1 ne ölçüde yaptığı da önemlidir. Yukarıdaki örnekte Ali'ye dört toplama işlemi verilmiş ve Ali bu işlemlerin tamamında elde olan sayıyı onlar basamağına eklemeden sonucu yazmıștır. Burada Ali'nin yaşadığı güçlüğün ne derecede olduğunu görmek mümkündür. Eğer Ali 4 denemenin ikisinde eklemeden işlemi yapsaydı eldeli toplama konusunda bazı kazanımlarının olduğu düşünülürdü.

Performans düzeyi ifade edilirken dikkat edilmesi gereken bir diğer önemli konu da bu ifadelerin değerlendirme verilerine dayalı olarak yazılmış olmasıdır (Gibb \& Dyches, 2000). Değerlendirme verilerine dayalı olmayan tahmini ifadeler kabul edilemez. Performans düzeyi yazılırken kullanılan değerlendirme aracı da belirtilmelidir.

Performans düzeyi yazımında yalnızca öğrencinin yapamadıkları değil güçlü olduğu yönler de ifade edilmelidir (Erbaş, 2003; Spinelli, 2002). Böylece öğrenci hakkında daha gerçekçi bir bakış açısı oluşturmak mümkün olacaktır.

Performans düzeyi öğrencinin o anki durumunu yansitmalıdır (Erbaş, 2003). Öğrencinin geçmişte yapamadıklarını performans ifadesi olarak almak, öğrenci performansı zaman içinde değişiklik gösterebileceğinden doğru değildir.

BEP'te yer alması gereken diğer iki öğe ise uzun dönemli ve kısa dönemli hedeflerdir. BEP bir akademik yıl için hazırlanan bir programdır. Belirlenecek hedefler de bir öğretim yılı içinde öğrenciye kazandırılacak davranışlar olarak belirlenir.
Uzun dönemli hedefler, bir öğretim y1lı içinde öğrenciye kazandırılacak davranışların bir listesidir. Uzun dönemli hedefler, kısa dönemli hedeflere göre daha geneldirler. Uzun dönemli hedefler, öğrenci performansına dayalı olarak öğrencinin bir akademik yıl içinde ulaşacağ 1 noktayı belirler. Öğrencinin BEP'te belirlenen hedeflere ulaşabilmesi için öncelikle hedeflerin gerçekçi bir biçimde belirlenmesi gerekmektedir. Hedefler ne ulaşılamayacak kadar güç, ne de çok kolay ulaşılabilir olmalıdır. Hedeflerin ulaşılamayacak kadar güç olması BEP'ın ve öğrencinin başarısını doğru bir biçimde yordamaya engel olacak, çok kolay olması da öğrenci için zaman kaybına yol açacaktır (Fiscuss \& Mandel, 1983; Gürsel, 2003).

Kısa dönemli hedefler, öğrencinin performans düzeyi ile uzun dönemli hedefler arasında yer alan ara basamaklardır. Kısa dönemli hedefler, uzun dönemli hedeflere göre daha özel ve ayrıntılıdır. Kısa dönemli hedef yazımının dört temel ilkesi vardır. Bunlar: 1. Birey, 2. Davranış, 3. Koşul, 4. Ölçüt. Kısa dönemli hedef yazarken kazandırılacak davranış hangi bireye öğretilecekse onun ismi yazılır. Öğretmen kısa dönemli hedefin öznesi olamaz. İkinci ilke davranıştır ve bu ilkede bireyin kazanacağı davranış açık, anlaşılır ve gözlenebilir bir biçimde ifade edilir. Kısa dönemli hedef ifadelerinde tek bir davranış yazılır. Üçüncü ilke, koşuldur. Koşul, hedef davranışın öğrenci tarafından öğrenildiğini kabul edebilmek için o davranışın nasıl, nerede, ne zaman ve hangi koşullar altında meydana gelmesi gerektiğinin ifadesidir. Dördüncü ilke olan ölçüt ise hedef davranışın bir öğrenci tarafından kazanıldığını söyleyebilmek için o davranışın öğrenci tarafından ne kadar doğrulukla gösterilmesi gerektiğinin yazılı ifadesidir.

BEP'te yer alması gereken bir diğer öğe ise belirlenen hedeflere ulaşmada kullanılacak olan öğretim yöntemleri ve materyalleridir. BEP öğrenci için yapılacak çalışmaların, ulaşılması beklenen hedeflerin dikkatli bir planıdır. Özel gereksinimli öğrenciler, müfredat hedeflerine ulaşmada güçlüklerle karşılaşan ve bunun için de desteğe ve uyarlamaya gereksinim duyan bireylerdir. Öğretim yöntemleri ve araçlarında uyarlamaların yapılması, öğrenciyi sınıfa dahil etme 
çabalarının başlangıcı olan gönderme öncesi süreçte başlar ve BEP sürecinde de devam eder. BEP sürecinde hedeflere ulaşmayı kolaylaştıracağı düşünülen öğretim yöntemi ve materyaller belirlenmelidir.

Kısa dönemli hedeflere ulaşmada gerekli olan zamanın başlama ve bitiş tarihleri BEP'nın içinde yer alır ve kısa dönemli her bir hedef için de düşünülen zaman ayrı ayrı belirlenir. Hedefler için ayrılan sürenin ne kadar olacağına öğrencinin engelden etkilenme derecesine, öğrenciye sağlanan destek eğitim hizmetlerine, öğrencinin ailesinin eğitime vereceği desteğe, öğretmene sağlanan destek eğitim hizmetlerine, sınıftaki öğrenci ve engelli öğrenci sayısına göre karar verilmelidir.

Belirlenen hedeflere ulaşılıp ulaşılmadığını belirlemek için kullanılacak değerlendirme yöntemi ve ölçütleri, BEP'te yer alması gereken bir diğer öğedir. İzleme, sistematik olarak uygulayıcılardan bilginin toplanması ve bu bilginin düzenli aralıklarla belirlenmiş olan amaçlarla karşılaştırılmasıdır. İzlemenin iki temel amacı vardır. Bunlardan birisi, BEP'i uygulamakla yükümlü olan uzmanlara, kullandıkları yöntemlerde gerekli değişiklikleri yapmak için sistematik olarak veri sağlamak, diğeri ise BEP'in uygulanmasını, planlanmış programın etkililiğini ve uygunluğunu değerlendirmede kullanılacak verileri BEP ekibine sağlamaktır. İzleme yoluyla BEP ekibi, uzun dönemli ve kısa dönemli hedeflerin gerçekleşip gerçekleşmediğini, uygulayıcıların sorumluluklarını yerine getirip getirmediklerini ve program değişikliklerinin belli bir birikime dayalı yapılıp yapılmadığını belirtir.

BEP'in değerlendirilmesi söz konusu olduğunda BEP ekibi tarafından en az yılda bir kez yapılan değerlendirmeden söz edilmektedir. BEP'in değerlendirilmesi iki amaca hizmet eder. Bunlardan birisi, öğrencinin uygulanmakta olan BEP ile iyi bir gelişme gösterip göstermediği ve programda değişikliklerin gerekli olup olmadığının belirlenmesidir. Değişiklikler amaç belirlemede, stratejilerde, yöntemlerde, materyallerde, kaynaklarda, uygulayıcılarda ve izleme sistemlerinde gerçekleştirilmelidir. Değerlendirmenin ikinci amacı ise, ekibin, BEP'i geliştirme ve uygulama, zamanı kullanma, iletişim, kayıtları tutma, uygun yerleştirme, hizmetlerin planlandığı şekilde zamanlanması ve sağlanmasında yeterli olup olmadığının belirlenmesidir. İyi bir izleme ve değerlendirme süreci için gerçekçi bir zaman çizelgesi ile sağlanan hizmetlerin başlangıç ve bitiş tarihleri belirlenmelidir. Ayrıca değerlendirme ölçütü, değerlendirmeyi kimin, nerede, hangi araçlarla, ne zaman ve hangi ölçütle yapacağ1 da belirlenmelidir. Değerlendirme sürecinde öğrencinin doğru programa yerleştirilip yerleştirilmediğinin de tekrar değerlendirilmesi önemli bir gerekliliktir ( Fiscuss ve Mandel, 1983) .

BEP'te yer alan son öğe ise öğrenciye sağlanacak ek özel eğitim hizmetlerinin nerede, ne zaman, kimler tarafından ve ne kadar süreyle verileceğinin belirlenmesidir (Heward, 2006). BEP başta da belirtildiği gibi hizmet alanlarla hizmet verenlerin üzerinde karşılıklı olarak anlaşmaya varmış oldukları bir sözleşmedir ve bu iki grup arasında karşılıklı koordinasyonu ve işbirliğini gerektirir. $\mathrm{Bu}$ nedenle öğrenci için çalışan tüm bireylerin, hangi görevleri, ne kadar süreyle, nerede ve kimler tarafından yerine getirileceği BEP içinde yer alır. Öğrencinin engelini göz önüne alarak onun ihtiyaçlarını karşılamaya çalışan ve özel olarak tasarlanmış konulardan oluşan "özel eğitim” genellikle özel eğitim öğretmenleri tarafından sağlanır. İlgili hizmetler ise diğer özel konu ve terapileri içeren ve öğrencinin bu yöndeki ihtiyaçlarını karşılamak için ilgili servis personeli tarafından sağlanan hizmetlerdir. Özel eğitim ve ilgili hizmetler sinavda, evde, hastanede ya da başka yerlerde sağlanabilir. İlgili hizmetlere konuşma -dil terapisi, psikolojik danışma ve rehberlik, fizyoterap örnek olarak verilebilir. İlgili hizmetler BEP hedeflerini başarabilmek için ihtiyaç duyulan yardımları içerir. Tablo 1'de öğrenci için sağlanacak özel eğitim ve ilgili hizmetlerin zaman çizelgesine ilişkin bir örnek yer almaktadır. Bu planlamanın öğrencinin BEP'ında yer alması, öğrenci için sağlanacak hizmetlerin bir bütünlük içinde görülmesini sağlar. 
Tablo 1

Öğrenci için Planlanan Destek Eğitim Planı

\begin{tabular}{|c|c|c|c|c|}
\hline $\begin{array}{l}\text { Hizmet-Yardım/ Destek } \\
\text { Türü }\end{array}$ & Yeri & $\begin{array}{l}\text { Haftalık/ } \\
\text { Günlük Zamanı }\end{array}$ & Başlama Tarihi & Süre \\
\hline Okuma konuları & Kaynak Oda & $30 \mathrm{dk} /$ gün & 03.11 .99 & $1 \mathrm{y} 1 \mathrm{l}$ \\
\hline Matematik konuları & Genel eğitim sınıfı & $30 \mathrm{dk} /$ gün & 03.11 .99 & $1 \mathrm{y} 1 \mathrm{l}$ \\
\hline Dil -konuşma & Konuşma Odası & $30 \mathrm{dk} /$ gün & 03.11 .99 & $1 \mathrm{y} 1 \mathrm{l}$ \\
\hline
\end{tabular}

Sonuç olarak, eğitsel değerlendirme ve BEP hazırlama süreci, özel gereksinimli bireylere sunulacak özel eğitim ve destek hizmetlerin bir sistem ve bütünlük içinde ele alınmasını gerektirir. Ancak bu bütünlüğün ve sistemin oluşturulabilmesi için sistemde yer alan her elemanın kendi görev ve sorumlulukları hakkında ayrıntılı bilgi sahibi olması, sürece ilişkin basamakların gereğini yerine getirmesi gerekmektedir.

Buna göre Şekil 2'de görüldüğü gibi eğitsel değerlendirme ve BEP sürecinde izlenmesi gereken basamaklar şöyle özetlenebilir. Engelli ya da risk grubunda yer alan çocuklar okul genelinde tarama çalışmaları ile belirlenmeli, bu belirlemenin ardından bu çocuklar için gönderme öncesi müdahale programları uygulanmalıdır. $\mathrm{Bu}$ programlarda özel gereksinimli öğrencilerin genel eğitim sınıflarına katılımlarını mümkün kılacak uyarlamalara yer verilmelidir. Bu sürecin belirli bir süre uygulanması sonucunda ortaya çıkan gelişmenin istendik yönde olmaması ya da hiçbir ilerleme görülmemesi durumunda, öğrencinin özel eğitim hizmetlerine uygun olup olmadığını belirlemek için rehberlik araştırma merkezine, gönderme raporu ile gönderilmesi sağlanmalıdır. RAM'de yapılacak değerlendirme süreci değerlendirme ekibi tarafından değerlendirmenin farklılık ilkesine uygun bir biçimde formal ve informal değerlendirme araçlarının birlikte kullanımıyla yapılmalı ve özel eğitim hizmetlerine uygun olduğu düşünülen öğrenciler, kendileri için belirlenen genel hedeflerle birlikte yerleştirilmelidirler.

Bireyselleştirilmiş eğitim programı yerleştirme yapılan okulda/kurumda bir ekip tarafindan hazırlanmalı, aile ve gerekli durumlarda bireyin kendisi de bu ekibin bir üyesi olarak çalışmalara katılmalıdır. BEP'nın uygulanmasının ardından, hazırlanan program ve öğrenci belirli aralıklarla değerlendirilmeli ve düzenli bir izleme çalışması yapılmalıdır. İzleme ve değerlendirme sonucunda bireyin özel eğitim hizmetlerine olan gereksinimi ortadan kalktığında özel eğitim hizmetleri sonlandırılmalıdır. 
Şekil 2

Ĕ̈itsel Değerlendirme ve BEP Hazırlama Süreci (Heward, L.W. 2006).

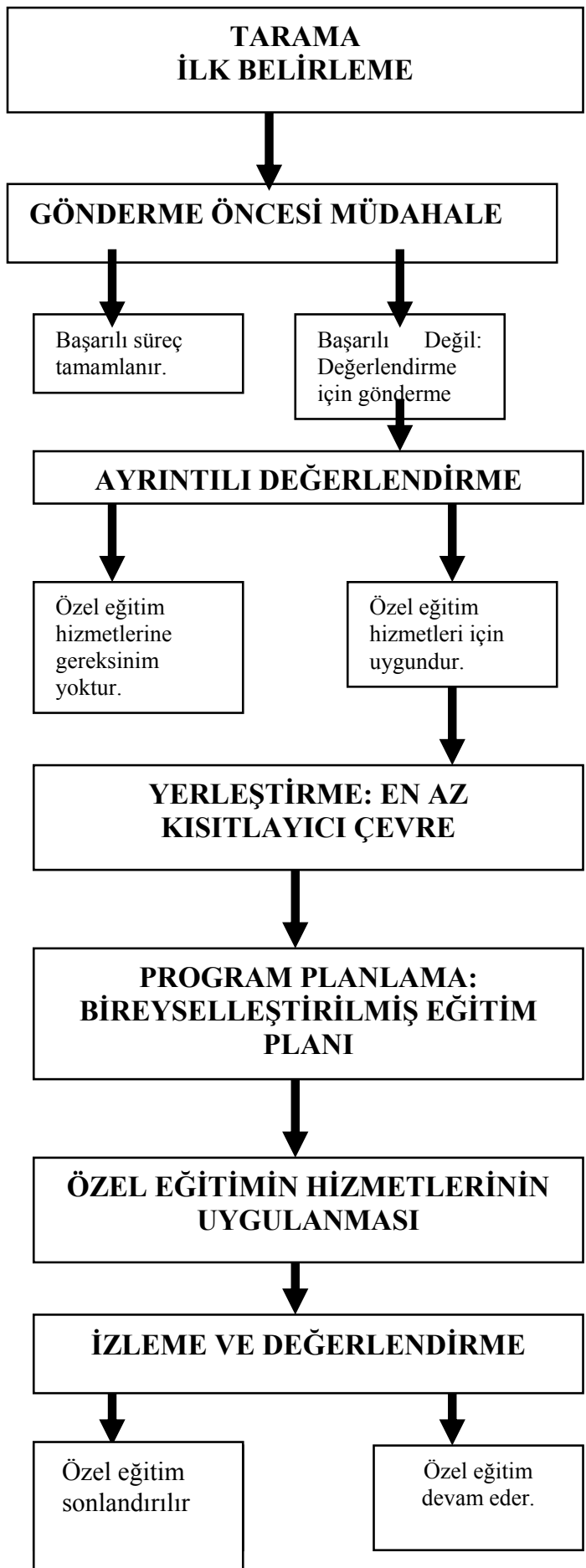




\section{KAYNAKÇA}

Erbaş, D. (2003). Varolan performans düzeyinin belirlengesi ve yazılması. O. Gürsel (Ed.). Bireyselleştirilmiş eğitim programlarının Geliştirilmesi (69-80). Eskişehir: Anadolu Üniversitesi Yayınları.

Fisscuss, D.E., \& Mandell, J.C. (1983). Developing individualized education programs. (Ed. Gönül Akçamete). Çev: Hatice Günayer Şenel, Elif Tekin. Ankara: Anı Yayıncılık.

Gibb, G.S. \& Dyches, T.T. (2000). Guide to writing quality individualized education programs : What's best for students? Boston: Allyn and Bacon.

Gürsel, O. (2003). Uzun ve kısa dönemli amaçların belirlenmesi ve yazılması. O. Gürsel (Ed.). Bireyselleştirilmiş eğitim programlarının geliştirilmesi (81-98). Eskişehir: Anadolu Üniversitesi Yayınları.

Heward, L.W. (2006). Exceptional children: An introduction to special education. (8th Edition). New Jersey: Pearson Prentice Hall.

Kirk, A. S.; Gallagher, J.J.; Anastasiow, J.N. \& Coleman, R.M.(2006). Educating exceptional children. (12th ed). Boston: Houghton Mifflin.

Milli Eğitim Bakanlığ1 (2000). Özel eğitim hakkında kanun hükmünde kararname ve özel ĕgitim hizmetleri yönetmeliği. Ankara: Milli Eğitim Basımevi.

Milli Eğitim Bakanlığı (2006). Özel eğitim hizmetleri yönetmeliği.

$\underline{\text { http://rega.basbakanlik.gov.tr/eskiler/2006/05/2006 }}$ 0531-2.htm
Mostropieri, A.M., \& Scruggs, E. T. (2000). The Inclusive classroom. Strategies for effective instruction. New Jersey: Prentice Hall.

Olson, J.L., \& Platt, C.J. (2004). Teaching children and adolescents with special needs. New Jersey: Prentice Hall.

Overton, T. (2006 ). Assesseing learners with special needs: an applied approach. (5th ed). New Jersey: Prentice Hall.

Salvia, J. \& Ysseldyke, E.J. (2001). Assessment. (8th ed.). Boston: Houghton Mifflin.

Spinelli, G. C. (2002). Classroom assessment for students with special needs in inclusive settings. New Jersey: Prentice Hall.

Strickland, B.B., \& Turnbull, A.P. (1990). Developing and implementing individualized education programs. Columbus $\mathrm{OH}$ : Merrill.

Sucuoğlu, B. \& Kargın, T.( 2006 ). Ilköğretimde kaynaştırma uygulamalarl: Yaklaşımlar, yöntemler, teknikler. İstanbul: Morpa

Taylor, L. R. (1997 ). Assessment of exceptioanl students: Educatioanl and psychological procedures. (4th ed.).Boston: Allyn and Bacon.

Tindal, G. A., \& Marston, D. B. (1990). Classroombased assessment: Evaluating instructional outcomes. Columbus, $\mathrm{OH}$ : Merrill.

Turnbull, A.; Turnbull, R. ve Wehmeyer, M. L. (2007) . Exceptional Lives: Special Education in today's schools. New Jersey: Prentice Hall.

Wood, W. (1998) Adapting instruction to accomodate students in inclusive settings. New Jersey: Prentice Hall. 
TEVHIDE KARGIN

2007, 8 (1) 


\section{Summary \\ The Process for Educational Assessment and Individualized Education Programme}

\section{Tevhide Kargın*}

For the past two decades, the field of special education has changed very rapidly and today a person with disabilities has more educational opportunities than the past in Turkey. The enactment of 573, Special Education Act, in 1997 and in 2005, marked significant procedural and programmatic changes to the educational services provided to students with disabilities. In these Acts, assessment and Individualized educational program (IEP) procedures were described.

Assessment is a critical component of the educational process and assessment refers to the gathering of relevant information to help individual make decisions. Assessment of students with disabilities, involves the collection of information that is the relevant in making decisions regarding initial identification and screening, current performance level, classification and placement, appropriate goals and objectives of IEP. Assessment process is required a team work and this team should include the general education teacher, special education teacher, school psychologist and any other individuals involved an a student's educational program. Assessment should be an active, ongoing and individualized process that clearly specified purpose.

Individualized educational program (IEP) is a part of assessment procedures. IEP is prepared after decisions about classification and program placement. In Turkey IEP is a legally mandatory and therefore it must be developed and implemented for each student who is eligible for the special education services. The IEP functions as a "contract" to identify goals, objectives, and timelines for delivery of services.

For an IEP, following components must be included:

1. Documentation of the student's current level of performance

2. Annual goals

3. Short-term objectives

4. Procedures and schedules for evaluating goals and objectives

5. Documentation of particular special education services that will provided for the student

6. Documentation of particular related services, if any, that will provided for the student

7. Projected dates for initiating services and anticipated duration services

8. As a consequence, assessment and IEP process is a legal requirement for Turkey. All these process can be helpful in making more systematically for conducting educational services for the people with disabled.

\footnotetext{
* Address for correspondence: Ankara Üniversitesi, Eğitim Bilimleri Fakültesi, Özel Eğitim Bölümü, Cebeci 06590, Ankara,Turkey E-mail: tkargin@hotmail.com
} 